\title{
Microsatellite Analysis in Post-Transplantation Lymphoproliferative Disorder to Determine Donor/Recipient Origin
}

Irene O.L. Ng, M.D., Tony W.H. Shek, M.D., Swan N. Thung, M.D., Michelle M.Q. Ye, M.D., Chung M. Lo, M.D., Sheung T. Fan, M.D., Joyce M.F. Lee, M.Sc., Kwok W. Chan, M.D.,

Annie N.Y. Cheung, M.D.

From the Departments of Pathology (IOLN, TWHS, JMFL, KWC, ANYC) and Surgery (CML, STF), the University of Hong Kong, Queen Mary Hospital, Hong Kong, and Department of Pathology, Mount Sinai Medical Center, New York, New York (SNT, MMQY)

Post-transplantation lymphoproliferative disorders (PTLD) are a group of heterogeneous diseases that occur after organ transplantation. Determination of the origin of the tumor cells not only provides clues to its possible pathogenetic mechanism, but also gives prognostic guidance in the clinical management of patients. We reviewed the clinicopathological features of four cases of PTLD that developed after solid organ transplantation. Using microsatellite analysis performed on paraffin-embedded tissue and using multiple, highly polymorphic markers, we have successfully determined the recipient/ donor origin of the tumor cells in all of them. The time of onset of the PTLD ranged from 5 to $11 \mathrm{mo}$. All cases were diffuse large cell lymphomas of B-cell lineage, and the two cases that have been tested for EBV by in situ hybridization were positive. Three of the 4 PTLD were of donor origin and these three patients died of diseases unrelated to PTLD. The single patient with PTLD of recipient origin died of disseminated PTLD. The mean survival length of the three patients with donor origin was $26.3 \mathrm{mo}$, whereas that of the patient with recipient origin was 12 mo. Our results indicate a relatively high incidence of PTLD of donor origin among our patients with solid organ transplantation, as compared to other reported series. Moreover, the finding of the relatively indolent nature of PTLD of donor origin supports that determination of the donor/recipient origin of PTLD is of prognostic significance.

Copyright () 2000 by The United States and Canadian Academy of Pathology, Inc.

VOL. 13, NO. 11, P. 1180, 2000 Printed in the U.S.A.

Date of acceptance: June 2, 2000.

This study was supported by a University CRCG grant (Grant no. 10202189) from the University of Hong Kong.

Address reprint requests to: Irene O.L. Ng, M.D., Room 127B, UPB, Department of Pathology, the University of Hong Kong, Queen Mary Hospital, Pokfulam, Hong Kong (no postal code required); e-mail: iolng@hkusua.hku.hk; fax: 852-2872-5197.
KEY WORDS: Donor/recipient origin, Microsatellite analysis, Post-transplantation lymphoproliferative disorder.

Mod Pathol 2000;13(11):1180-1185

Post-transplantation lymphoproliferative disorder (PTLD) is one of the complications of solid organ transplantation. It occurs in about 2 to $3 \%$ of patients after solid organ transplantation (1), and the exact incidence appears to be related to the degree of immunosuppression. PTLD encompasses a histologically and biologically diverse group of diseases that include the entire spectrum of lymphoid proliferative lesions, ranging from purely reactive lesions consisting of polymorphic B-cell hyperplasia to frankly neoplastic lesions of non-Hodgkin's lymphoma, which is characterized by clonal proliferation of B-cells (2).

Because of the presence of foreign allograft organ in the host, PTLD can be of either donor or recipient origin. There have been a number of techniques that can be employed to determine the origin of the tumor cells in PTLD, such as sex chromosome ISH $(3,4)$, HLA-typing, and the study of restriction fragment length polymorphism (5). These methods have their limitations, and may not be applicable in every single case. For example, the analysis of sex chromosome requires a sex mismatch between the donor and the recipient. Furthermore, there is a possibility, though slight, that the $\mathrm{X}$ - and/or Y-chromosome in the tumor cells are derived from previous blood transfusions, and not from the allograft donor. Additionally, many of these tests require fresh tissue, which precludes their applicability in formalin-fixed, paraffin-embedded tissue.

Microsatellites are small nucleotide repeats scattered throughout the genome. They are stably inherited and highly heterogeneous among individuals. Analysis of the microsatellites is, therefore, 
useful in determining the origin of the tumor cells in PTLD where the host harbors two different sets of microsatellite alleles, one of his own, and the other from the donor. Another advantage of using microsatellite analysis is that it is applicable in formalin-fixed, paraffin-embedded tissue, which allows archival material to be analyzed. Moreover, microsatellite analysis can be performed quickly and requires only small amounts of tissue.

In this study, we review the clinicopathologic features of four cases of PTLD, and determine the origin of the tumor cells by means of microsatellite analysis using multiple polymorphic markers. A literature review of the reported cases of PTLD using microsatellite analysis to determine donor/recipient origin of the tumors is also presented.

\section{MATERIALS AND METHODS}

\section{Patients}

Four cases of PTLD after solid organ transplantation were identified in the files of Departments of Pathology at Queen Mary Hospital, Hong Kong, and Mount Sinai Medical Center, New York, New York. The clinical records and pathologic materials were retrieved and reviewed.

\section{Histology and Immunohistochemistry}

The histologic sections of formalin-fixed, paraffinembedded tissues were examined after routine staining with hematoxylin and eosin. Immunohistochemical studies were performed on formalinfixed, paraffin-embedded tissue using monoclonal antibodies to B-cell (CD79a, Dakopatts, Glostrup, Denmark; and CD20, Dakopatts), T cell (CD3, Becton Dickinson, San Jose, CA; and UCHL1, Dakopatts); and polyclonal antibodies to $\lambda$ and $\kappa$ light chains (Dakopatts).

\section{DNA Extraction}

DNA was extracted from formalin-fixed, paraffinembedded tissue samples. Ten- $\mu$ m-thick sections were cut and careful microdissection was performed on the cut sections to avoid contamination of tissues. To extract DNA, cells were lysed in buffer with proteinase $\mathrm{K}$ and incubated at $42^{\circ} \mathrm{C}$ overnight with constant gentle agitation. DNA was isolated by phenol-chloroform, precipitated, air-dried and resuspended in 5 mм EDTA, pH 8.0. The concentrations of the extracted DNA were estimated by spectrophotometry. In Case 1, the donor and recipient tissues were from the gall bladders of the donor and recipient respectively. In Case 2, the donor tissue was from the allograft kidney and the recipient tissue from her gastric biopsy. In both Cases 3 and 4 , the donor tissues were from the donor gall bladders and recipient tissues from the explanted livers.

\section{PCR and Microsatellite Analysis}

A total of eight primers were used in the present study. These loci are located on chromosome 1 and 9, and included MYCL1 (1p32), D9S270 (9p21), D9S304 (9p21), D9S162 (9p23-22), D9S168 (9p2322), D9S199 (9p23), D9S269 (9p23-22), and D9S176 (9q22.3) (Research Genetics, Huntville, AL) (Table 1). They are polymorphic di- or tetranucleotiderepeat microsatellite markers with a high percentage of heterozygosity. Polymerase chain reaction (PCR) reaction was performed in a $20-\mu \mathrm{L}$ reaction volume that contained $100 \mathrm{ng}$ of genomic DNA, 125 $\mu \mathrm{M}$ each dNTP, $2 \rho \mathrm{mol}$ each of forward and reverse primers, $0.2 \mathrm{U}$ of $\mathrm{Taq}$ polymerase and $2 \mu \mathrm{L} 10 \times$ Buffer (10 mm Tris-HCl, $50 \mathrm{~mm} \mathrm{KCl,} \mathrm{0.1 \%} \mathrm{TritonX-}$ 100 ), and 1.0 or $1.5 \mathrm{~mm}$ magnesium chloride. The forward primer was end-labeled with $\left[\gamma_{-}{ }^{33} \mathrm{P}\right]$ ATP by T4 polynucleotide kinase. The PCR reaction consisted of an initial denaturation step at $94^{\circ} \mathrm{C}$ for 5 min, followed by four cycles of touch-down PCR denaturation at $94^{\circ} \mathrm{C}$ for $1 \mathrm{~min}$, with $1 \mathrm{~min}$ of annealing at $60^{\circ}, 59^{\circ}, 58^{\circ}, 57^{\circ} \mathrm{C}$ and extension at $72^{\circ}$ $\mathrm{C}$ for $1 \mathrm{~min}$ and 30 cycles of denaturation at $94^{\circ} \mathrm{C}$ for $1 \mathrm{~min}$, annealing at $56^{\circ} \mathrm{C}$ for $1 \mathrm{~min}$, with extension at $72^{\circ} \mathrm{C}$ for $1 \mathrm{~min}$ and a final extension at $72^{\circ}$ $\mathrm{C}$ for $7 \mathrm{~min}$. After dilution with an adequate volume of formamide dye mixture $(98 \%$ formamide, $0.1 \%$ bromophenol blue, $0.1 \%$ xylene cyanol, $10 \mathrm{~mm}$ EDTA), PCR products were heat-denatured $\left(80^{\circ} \mathrm{C}, 5\right.$ min), chilled on ice and electrophoresed on $6 \%$ polyacrylamide gel containing $8 \mathrm{M}$ salts at $1500 \mathrm{w}$

TABLE 1. Oligonucleotide Primers of Microsatellites Used in This Study

\begin{tabular}{|c|c|c|c|c|c|c|}
\hline $\operatorname{Loci}^{a}$ & Location & $\begin{array}{l}\text { Length } \\
\text { (bp) }\end{array}$ & $\begin{array}{c}\text { Nucleotide } \\
\text { Repeat }\end{array}$ & Heterozygosity & Forward primer sequence & Reverse primer sequence \\
\hline MYCL1 & $1 \mathrm{p} 32$ & 140-209 & GAAA & 0.87 & TGGCGAGACTCCATCAAAG & CCTTTTAAGCTGCAACAATTTC \\
\hline D9S270 & $9 p 21$ & $87-101$ & CA & 0.71 & AGGTGTAGTCCTTCTGGAATTT & GATGTGACTGCTGTTAAAACTAGAG \\
\hline D9S304 & 9 p21 & 164 & GATA & 0.85 & GTGCACCTCTACACCCAGAC & TGTGCCCACACACATCTATC \\
\hline D9S162 & $9 p 23-22$ & $172-196$ & $\mathrm{CA}$ & 0.75 & GCAATGACCAGTTAAGGTTC & ААТTСССАСААСАААТСТСС \\
\hline D9S168 & $9 p 23-22$ & $227-247$ & CA & 0.76 & GGTTTGTGGTCTTTGTAAGG & TGGTTTGTTTGTATAACTATCATTG \\
\hline D9S199 & 9 p23 & $144-164$ & CA & 0.77 & ACACATTCATACCATAGCAGAGG & GGGGAAAGCATTCAGACTTT \\
\hline D9S269 & $9 p 23-22$ & $171-250$ & CA & 0.75 & TTCCAGAAATAGCCCGC & CTGTAACCCCAAAGATAAGAATG \\
\hline D9S176 & $9 q 22.3$ & $129-147$ & CA & 0.82 & AGCTGGCTGTTGGAGAAA & TGACCAATGGCAGGGTAT \\
\hline
\end{tabular}

${ }^{a}$ References are from the Genome Data Base, an international collaboration hosted by Johns Hopkins University School of Medicine. 
for 2 to $3.5 \mathrm{hr}$, depending on the PCR product size. The gels were vacuum-dried at $80^{\circ} \mathrm{C}$ and exposed overnight to Fuji film at $-80^{\circ} \mathrm{C}$ with intensifying screen.

In Situ Hybridization for Epstein-Barr Virus (EBV)

A DNA fragment containing EBER1 and EBER2 (nucleotides 6661 to 7119 of EBV) was cloned into the Bluescript vector, from which digoxigeninlabeled antisense RNA probes were generated by in vitro transcription. In situ hybridization for EBER was performed on formalin-fixed, paraffinembedded tissue using the method we previously described (6).

\section{RESULTS}

\section{Clinical Findings}

The clinicopathologic features of the four cases of PTLD were listed in Table 2.

\section{Histopathology and Immunohistochemistry}

The histologic findings in these four cases were very similar. There was a diffuse infiltration of a monotonous population of large lymphoid cells in the involved organs (Fig. 1). Extension into the perinephric adipose tissue was also noted in Case 2 (renal allograft). Immunohistochemical studies showed that these abnormal lymphoid cells were immunoreactive for B-cell markers CD79a and CD20. $\lambda$ light chain restriction was demonstrable by immunohistochemistry in two cases (Cases 1 and 2). The overall features were those of a diffuse large B-cell lymphoma, which were morphologically indistinguishable from similar lymphoma occurring in immunocompetent individuals.

\section{Microsatellite Analysis}

The results of the microsatellite analysis were summarized in Table 3. For those loci that were informative, the results were consistent. In three of the four patients, the genetic origin of PTLD was shown to be of donor origin. The remaining case (Case 4) was of recipient origin (Fig. 2).

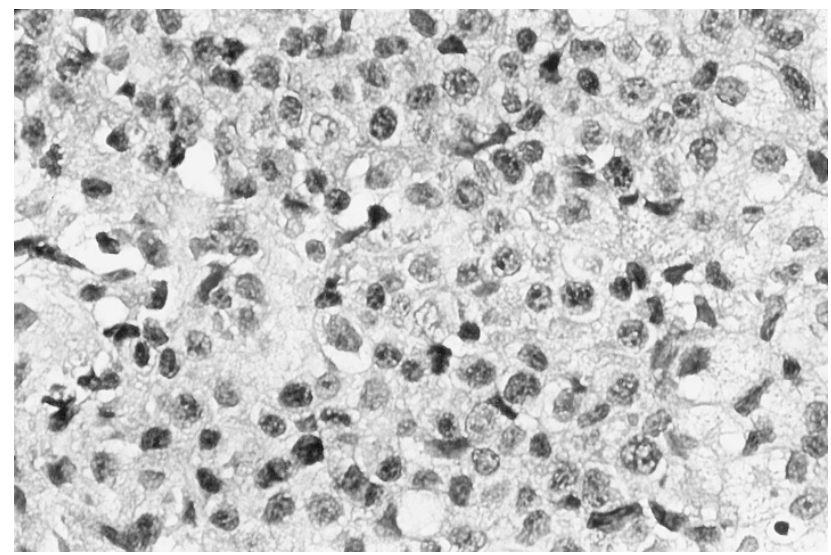

FIGURE 1. Case 1. The liver mass showed diffuse infiltration by medium to large-sized lymphoid cells resembling centroblasts (original magnification, $550 \times$ ).

\section{In Situ Hybridization for EBV}

The two cases (Cases 1 and 2) tested for EBER by in situ hybridization showed nuclear signal in almost every lymphoma cell (Fig. 3).

\section{Literature Review}

The previously reported cases of PTLD in solid organ transplantation using microsatellite analysis to determine the donor/recipient origin of the tumors are listed in Table 4. There have been a total of 27 cases of PTLD in solid organ transplantation using microsatellite analysis reported in the literature and in the present study. Sixteen (59\%) cases were of recipient origin and eleven of donor origin. Of the eleven cases of recipient-origin tumor with sites of tumor specified, eight $(72.7 \%)$ were disseminated with individual tumors involving two or more organs. In contrast, all of the nine donororigin lymphomas with sites of tumors specified were localized to the allografts and none were disseminated.

\section{DISCUSSION}

Because allograft recipients harbor both donor and recipient lymphocytes, PTLD can potentially arise from either donor or recipient lymphoid tissue. In bone marrow transplantation, the PTLDs are

TABLE 2. Clinicopathological Parameters of the Four Patients with Post-Transplantation Lymphoproliferative Disorders

\begin{tabular}{|c|c|c|c|c|c|c|c|c|c|}
\hline $\begin{array}{l}\text { Gender/ } \\
\text { Age }\end{array}$ & Allograft & $\begin{array}{c}\text { Time After } \\
\text { Transplantation }\end{array}$ & Location & Lineage & Type & Origin & EBV & Cause of Death & $\begin{array}{c}\text { Survival After } \\
\text { Diagnosis of } \\
\text { PTLD }\end{array}$ \\
\hline $\mathrm{M} / 37$ & Liver & $8 \mathrm{mo}$ & Liver & B & DLCL & Donor & Positive & Allograft rejection & $11 \mathrm{mo}$ \\
\hline $\mathrm{F} / 29$ & Kidney & $5 \mathrm{mo}$ & Kidney & B & DLCL & Donor & Positive & Chronic renal failure & $50 \mathrm{mo}$ \\
\hline $\mathrm{F} / 52$ & Liver & 9 mo & Liver & B & DLCL & Donor & ND & Pneumonia & $18 \mathrm{mo}$ \\
\hline $\mathrm{F} / 67$ & Liver & $11 \mathrm{mo}$ & Liver \& lung & B & DLCL & Recipient & ND & PTLD & $12 \mathrm{mo}$ \\
\hline
\end{tabular}

DLCL, diffuse large cell lymphoma, EBV, positive by in situ hybridization for EBER; ND, not done. 
TABLE 3. Results of Microsatellite Analysis of the PTLD

\begin{tabular}{|c|c|c|c|c|c|c|c|c|}
\hline Case No. & MYCL1 & D9S162 & D9S168 & D9S199 & D9S269 & D9S176 & D9S304 & D9S270 \\
\hline 1 & - & $\mathrm{D}$ & $\mathrm{D}$ & $\mathrm{D}$ & NI & $\mathrm{D}$ & NI & $\mathrm{D}$ \\
\hline 2 & - & $\mathrm{D}$ & $\mathrm{D}$ & $\mathrm{D}$ & $\mathrm{D}$ & $\mathrm{D}$ & $\mathrm{D}$ & - \\
\hline 3 & $\mathrm{D}$ & - & - & NI & $\mathrm{D}$ & - & $\mathrm{D}$ & $\mathrm{D}$ \\
\hline 4 & $\mathrm{R}$ & - & - & $\mathrm{R}$ & $\mathrm{R}$ & - & NI & NI \\
\hline
\end{tabular}

D, PTLD of donor origin; R, recipient origin; NI, non-informative with microsatellite patterns indistinguishable between donor and recipient.

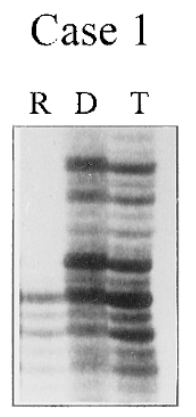

D9S270

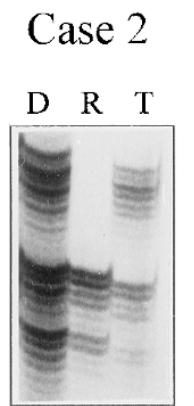

D9S162

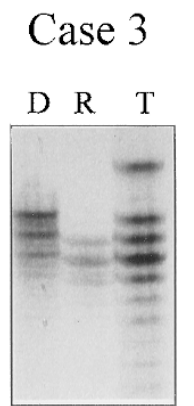

D9S269
Case 4

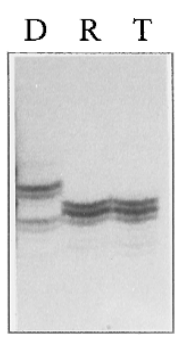

MYCL1
FIGURE 2. Representative results of microsatellite analysis of the four cases. Lanes: R, recipient; D, donor; T, PTLD. In Cases 1 through 3, the alleles of the individual tumors matched with those of the corresponding donor tissues. In Case 4, the alleles of the tumor matched with those of the recipient tissue.

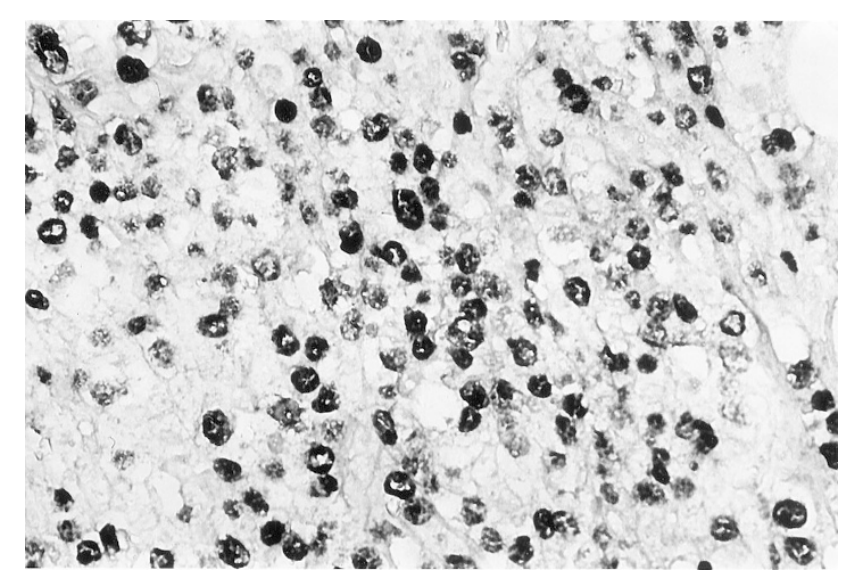

FIGURE 3. Most of the lymphoma cells are positive for in situ hybridization for EBER (original magnification, $420 \times$ ).

predictably of donor origin (5) because the lymphoid cells of the host are depleted by conditioning therapies, a finding confirmed by multiple studies. On the other hand, in solid organ transplantation, because there are only relatively few donor lymphocytes in a solid organ allograft, most of the PTLDs are expected to be of recipient origin. In fact, the majority (60 to $70 \%$ ) of the reported cases were of recipient origin $(7,8)$. We notice, however, an unusually high percentage of donor-origin PTLD in the present series, which amounts to $75 \%$ of the cases. In fact, it is intriguing to note that, of the total 27 cases of PTLD in solid organ transplantation using microsatellite analysis reported in the literature and in the present study, almost all (10/11) of the PTLD of donor origin arose in liver transplant recipients, whereas most (14/16) of the PTLD of recipient origin arose in recipients of other solid organs $(P<.0001)$.

All four cases of PTLD in this series were of B-cell lineage. They were histologically diffuse large B-cell lymphoma, and were very similar to one another. They occurred at an average of 8.25 mo after transplantation. Three cases were found to be of donor origin with microsatellite analysis, and the lymphoproliferative disease was confined to the allograft. Clinically, the lymphomas in these three patients were indolent, with no evidence of disseminated disease clinically. In fact, in Case 2, the lymphoma was only detected incidentally in the renal allograft removed for chronic rejection. All of these three patients with donor-origin disease died of diseases unrelated to PTLD. On the other hand, in the case shown to be of recipient origin, the lymphoproliferative disease was disseminated and was the cause of death. Furthermore, the mean survival length of the three patients with donor-origin disease was longer $(26.3 \mathrm{mo})$ than that of the patient with recipient-origin disease $(12 \mathrm{mo})$. However, the number of cases in this study was too small for statistical analysis. Nevertheless, the findings support that determination of the donor/recipient origin of the PTLD is of clinical and prognostic importance.

The finding that determination of donor/recipient origin of the PTLD is of prognostic significance in the present study is in accordance with the experience of others $(7,9,10,11)$. It has been shown that PTLD of recipient origin are more often aggressive, widely disseminated, and highly lethal, whereas PTLD of donor origin tend to be localized to the allograft and more indolent $(7,9,10,11)$. For instance, Weissman et al. (7), combining the cases of their group and those reported in the literature, found that two-thirds $(12 / 18)$ of the patients with recipient-origin tumors were dead of disease or alive with disease, whereas all four patients with donor-origin tumors were free of disease whether alive or dead.

The precise pathogenesis of PTLD is unknown, but a combination of impaired immunity, oncogenic consequences of immunosuppressive therapy, and EBV infection may play a role. Furthermore, the incidence of PTLD is proportional to the 
TABLE 4. Clinicopathological Features of PTLD and Results of Microsatellite Analysis Reported in the Literature in Solid Organ Transplantation

\begin{tabular}{|c|c|c|c|c|c|c|c|c|}
\hline Authors & Sex/Age & $\begin{array}{c}\text { Allograft } \\
\text { Transplanted }\end{array}$ & Type & Lineage & PTLD Site & Origin & $\begin{array}{c}\text { Time after } \\
\text { transplantation } \\
\text { (mo) }\end{array}$ & $\begin{array}{l}\text { Tissue material } \\
\text { analyzed }\end{array}$ \\
\hline \multirow{10}{*}{ Weissmann et al. (7) } & $\mathrm{F} / 46$ & Kidney & DLCL & B & Kidney (hilum) & Recipient & 52 & Frozen \\
\hline & $\mathrm{M} / 47$ & Heart & DLCL & B & Liver & Recipient & 37 & Frozen \\
\hline & $\mathrm{M} / 45$ & Heart & DLCL & B & Lung & Recipient & 8 & Frozen \\
\hline & $\mathrm{F} / 50$ & Kidney & DLCL & B & Kidney \& disseminated & Recipient & 2 & Frozen \\
\hline & $\mathrm{M} / 8$ & $\begin{array}{l}\text { Liver \& } \\
\quad \text { intestine }\end{array}$ & DLCL & B & Liver, LN and CNS & Recipient & 6 & Frozen \\
\hline & $\mathrm{M} / 60$ & Heart & DLCL & B & Heart \& disseminated & Recipient & 10 & Frozen \\
\hline & $\mathrm{F} / 55$ & Kidney & DLCL & $\mathrm{T}$ & Vulva \& abdominal skin & Recipient & 61 & Frozen \\
\hline & $\mathrm{M} / 63$ & Heart & BL & B & Disseminated LN \& skin & Recipient & NS & Frozen \\
\hline & $\mathrm{F} / 56$ & Kidney & BL-like & B & Intestines \& CNS & Recipient & 4 & Frozen \\
\hline & $\mathrm{M} / 55$ & Kidney & DLCL & B & Colon \& liver & Recipient & 18 & Frozen \\
\hline \multirow[t]{5}{*}{ Larson et al. (8) } & $\mathrm{M} / 30$ & Kidney & DLCL & B & NS & Recipient & 1.5 to 168 & FP \\
\hline & $\mathrm{M} / 5$ & Heart & BL-like & B & NS & Recipient & NS & FP \\
\hline & $\mathrm{M} / 58$ & Kidney & DLCL & B & NS & Recipient & NS & FP \\
\hline & $\mathrm{M} / 68$ & Heart & ALCL & $\mathrm{T}$ & NS & Recipient & NS & FP \\
\hline & $\mathrm{M} / 43$ & Kidney & PTCL & $\mathrm{T}$ & NS & Recipient & NS & FP \\
\hline Weissmann et al. (7) & $\mathrm{M} / 57$ & Liver & DLCL & B & Liver (hilum) & Donor & 5 & Frozen \\
\hline Spiro et al. (9) & $\mathrm{M} / 57$ & Liver & BL-like & B & Liver (hilum) & Donor & 5 & Frozen \\
\hline \multirow[t]{2}{*}{ Armes et al. (10) } & $\mathrm{M} / 39$ & Liver & DLCL & B & Liver (hilum) & Donor & 7 & FP \\
\hline & $\mathrm{M} / 52$ & Liver & PMLP & B & Liver (hilum) & Donor & 7 & FP \\
\hline \multirow[t]{2}{*}{ Larson et al. (8) } & $\mathrm{F} / 59$ & Kidney & PMLP & B & NS & Donor & NS & FP \\
\hline & $\mathrm{M} / 39$ & Liver & DLCL & B & NS & Donor & NS & FP \\
\hline \multirow[t]{2}{*}{ Strazzabosco et al. (11) } & $\mathrm{M} / 48$ & Liver & DLCL & B & Liver (hilum) & Donor & 5 & FP \\
\hline & $\mathrm{M} / 54$ & Liver & DLCL & B & Liver (hilum) & Donor & 3 & Frozen \\
\hline
\end{tabular}

DLCL, diffuse large-cell lymphoma; BL, Burkitt's lymphoma; PMLP, polymorphic B-cell lymphoma; ALCL, anaplastic large cell lymphoma; LN, lymph node; CNS, central nervous system; FP, formalin-fixed, paraffin-embedded; NS, not specified.

degree of immunosuppression, and studies have shown that up to $10 \%$ of patients with combined heart and lung transplantation may develop PTLD (12), whereas only $1 \%$ of patients with renal transplantation develop PTLD. In addition, patients receiving anti-CD3 monoclonal antibodies treatment have also been shown to have an increased risk of PTLD (13). On the other hand, it has been speculated that early reduction of cyclosporin-A dosage may reduce the subsequent risk of PTLD development (13). The role EBV plays in the pathogenesis of PTLD is not fully understood, but virtually all PTLD are EBV-related. Indeed, the persistent presence of EBV in PTLD has enabled diagnostic surgical pathologists to distinguish between PTLD and acute cellular rejection in liver transplantation (14), which show considerable morphologic overlap.

To conclude, determination of donor/recipient origin of PTLD is of prognostic and clinical significance. Such differentiation of the donor/recipient origin of the tumor can be readily achieved with microsatellite analysis that is applicable in formalin-fixed, paraffin-embedded tissue and therefore allows archival material to be analyzed. This is particularly useful in routine specimens that are usually fixed in formalin and embedded in paraffin.

\section{REFERENCES}

1. Nalesnik MA, Jaffe R, Starzl TE, Demetris AJ, Porter K, Burnham JA, et al. The pathology of posttransplant lymphopro- liferative disorders occurring in the setting of cyclosporine A-prednisone immunosuppression. Am J Pathol 1988;133: 173-92.

2. Knowles DM, Cesarman E, Chadburn A, Frizzera G, Chen J, Rose EA, et al. Correlative morphologic and molecular genetic analysis demonstrates three distinct categories of posttransplantation lymphoproliferative disorders. Blood 1995; 85:552-65.

3. Lones MA, Lopez-Terrada D, Shintaku IP, Rosenthal J, Said JW. Posttransplant lymphoproliferative disorder in pediatric bone marrow transplant recipients: disseminated disease of donor origin demonstrated by fluorescence in situ hybridization. Arch Pathol Lab Med 1998;122:708-14.

4. Cheung ANY, Chan ACL, Chung LP, Chan TM, Cheng IK, Chan KW. Post-transplantation lymphoproliferative disorder of donor origin in a sex-mismatched renal allograft as proven by chromosome in situ hybridization. Mod Pathol 1998;11:99-102.

5. Shapiro RS, McClain K, Frizzera G, Gajl-Peczalska KJ, Kersey $\mathrm{JH}$, Blazar BR, et al. Epstein-Barr virus associated B cell lymphoproliferative disorders following bone marrow transplantation. Blood 1988;71:1234-43.

6. Shek TWH, Ho FCS, Ng IOL, Chan AC, Ma L, Srivastava G. Follicular dendritic cell tumor of the liver. Evidence for an Epstein-Barr virus-related clonal proliferation of follicular dendritic cells. Am J Surg Pathol 1996;20:313-24.

7. Weissmann DJ, Ferry JA, Harris NL, Louis DN, Delmonico F, Spiro I. Posttransplantation lymphoproliferative disorders in solid organ recipients are predominantly aggressive tumors of host origin. Am J Clin Pathol 1995;103:748-55.

8. Larson RS, Scott MA, McCurley TL, Vnencak-Jones CL. Microsatellite analysis of posttransplant lymphoproliferative disorders: determination of donor/recipient origin and identification of putative lymphomagenic mechanism. Cancer Res 1996;56:4378-81.

9. Spiro IJ, Yandell DW, Li C, Saini S, Ferry J, Powelson J, et al. Lymphoma of donor origin occurring in the porta hepatis of a transplanted liver. N Engl J Med 1993;329:27-9. 
10. Armes JE, Angus P, Southey MC, Battaglia SE, Ross BC, Jones $\mathrm{RM}$, et al. Lymphoproliferative disease of donor origin arising in patients after orthotopic liver transplantation. Cancer 1994;74:2436-41.

11. Strazzabosco M, Corneo B, Iemmolo RM, Menin C, Gerunda G, Bonaldi L, et al. Epstein-Barr virus-associated post-transplant lympho-proliferative disease of donor origin in liver transplant recipients. J Hepatol 1997;26:92634 .
12. Opelz G, Henderson R. Incidence of non-Hodgkin lymphoma in kidney and heart transplant recipients. Lancet 1993;342:1514-6.

13. Penn I. Cancer complicating organ transplantation. N Engl J Med 1990;118:667-75.

14. Rizkalla KS, Asfar SK, McLean CA, Garcia BM, Wall WJ, Grant DR. Key features distinguishing post-transplantation lymphoproliferative disorders and acute liver rejection. Mod Pathol 1997;10:708-15.

\section{Book Review}

\section{Young, NS: Bone Marrow Failure Syndromes, 223 pp, Philadelphia, W.B. Saunders, 2000 (\$125)}

Bone marrow failure was first recognized in bicycle tire workers exposed to benzene in 1897. Fanconi, a Swiss pediatrician, described pancytopenia, hyperpigmentation, and skeletal malformations in three brothers in 1927. Myelodysplasia is a clonal, proliferative stem cell disorder paradoxically manifesting cytopenia. Paroxysmal nocturnal hemoglobinuria is another clonal disorder that lacks numerous molecules attached to the red blood cell membrane because of a particular glycolipid anchor defect. Thirteen experts contributing 10 chapters exhaustively describe the implications for anemia, leukopenia, and thrombocytopenia of these diverse conditions, plus others. Focused chapters review human immunodeficiency virus, Fanconi's anemia, myelodysplasia, paroxysmal nocturnal hemoglobinuria, pure red cell aplasia, T-cell large granular lymphocyte lymphoproliferative disorder, agranulocytosis, and myelofibrosis.
Infectious, malignant, hereditary, and acquired conditions yield various cytopenias. In part, it could be suggested that bone marrow failure remains a fearful, poorly understood concept because its diverse causes are rarely considered together as a group of related syndromes. This new book should hep educate and stimulate debate. Clear line drawings illustrate relevant molecular, biochemical, and immunologic pathogenetic mechanisms. Abundant tables summarize differential diagnostic features. Perhaps of less interest to pathologists, there are also recommendations for therapy. Overall, this is an impressive reference work for a frequently confounding group of hematologic diseases.

\author{
Howard Ratech \\ Montefiore Medical Center \\ Albert Einstein College of Medicine \\ Bronx, New York
}

